\title{
The Effect of Using Mobile Banking Services Applications on Electronic Word of Mouth: The Mediating Role of Perceived Trust
}

\author{
Lama Zalloum $^{1}$, Hamad Alghadeer ${ }^{1}$, Nawras Nusairat ${ }^{1}$ \\ ${ }^{1}$ Faculty of Business, Applied Science University, Amman, Jordan \\ Correspondence: Hamad Alghadeer, Faculty of Business, Applied Science University, Amman, Jordan.
}

Received: July 8, 2019

Accepted: August 12, 2019

Online Published: August 27, 2019

doi:10.5539/ibr.v12n9p62

URL: https://doi.org/10.5539/ibr.v12n9p62

\begin{abstract}
The objective of this study is to examine selected dimensions of mobile banking, (such as Ease of Navigation, Personalization Level, Information Quality, Rewards) on e-wom through the mediating role of perceived trust. Self-structured questionnaire is used to collect data which is then shared via Google forms online and targeted only to the users of mobile banking services application in Jordan. Quantitative and analytical methods were used to analyze the data. 499 questioners were returned, 30 of which were rejected as they were not using mobile banking service applications. 469 of the questionnaires were accepted and analyzed using reliability test analysis, descriptive statistics and regression process.

The findings of the study indicate that there is a statistically significant effect of mobile banking (Ease of Navigation, Personalization Level, Information quality, Rewards) through the mediation role of perceived trust on relationships between using mobile banking services and e-wom. It is recommended that banks pay more attention to mobile banking and build powerful and good E-WOM in order to spread the use of mobile banking rapidly.
\end{abstract}

Keywords: mobile banking, e-wom, Banks, perceived trust, Jordan

\section{Introduction}

The world is changing and how work is done in business has changed. Internet, smart phones, applications and social media have given organizations the opportunity to directly communicate with their customers and easily establish a close relationship with them (Yan, Shah, Zhai, Khan, Shah, 2018). Almost all banks in recent years have become interested in internet and mobile banking (E.Basci, 2014). Consumers used to perform their bank transactions through Automated Teller Machines (ATM), over the phone, or by using Internet banking. Now companies have replaced these traditional ways and introduced an easier way for their customers to complete their transaction with just one click on their mobile application (Bagudu, Khan, Roslan, 2017).

Internet banking has effectively changed bank work. It has accelerated the attaining and processing of information, displaying it to users without delay and at any time they choose (AlKailani, 2016). The idea of banks is based on the trust that a customer's money will be secure. This is an extremely sensitive issue for banks thus they are highly interested in safeguarding the security of their services and strive to improve internet and mobile banking in order to ensure customers feel safe and supported with every step they make on their account (Anton, 2014).

Most banks found that if they provided internet banking, it improved their service quality and more customers established a direct relationship with them. This resulted in an increase in revenue, higher profit, lower costs and reduced risk (Kombe and Wafula, 2015).

The use of mobile phones has greatly changed customer behavior as they are able to complete so many tasks on this one device. As such, customers have become accustomed to speedy transactions. Companies have noticed the reliability of smart phones and recognize the willingness of their customers to use this device to complete their daily tasks. This lead banks to take massive strides in expanding their internet and mobile banking services (Perdigoto and Picoto, 2014).

Mobile banking is defined as an application via wireless network connecting banks with their customers, 
providing them with financial services like billing payment or non-financial services like account balance request through smart phone or tablet (Shaikh and Karjaluoto, 2016). In recent years the use of mobile banking applications has increased in Jordan. Banks encourage their customer to use mobile banking as this allows them to reach more customers and gain their satisfaction and loyalty. The use of mobile banking application also minimizes labor costs (Alalwan, Dwivedi, Rana, Lal, Williams, 2015).

Customers have become familiar with e-wom on social media, posting comments, reviews and sharing personal experiences with more potential customers, assisting them in making decisions about products they may be interested in. (Saleem and Ellahi, 2017). Nowadays, when consumers need a product or service, they turn to their smart phones and search for information on websites, applications and social media in order to find the product or service that best fits their needs (Erkan and Evans, 2016).

E-wom is sharing your opinion, feelings and attitudes with groups of people on any subject matter through Internet (Ishida, Slevitch and Siamionava 2016). There is no longer any need to use traditional media or traditional word of mouth (WOM) as mobiles and social networks have created a new WOM. Online communities where people share the same interests, company pages that consumers can directly communicate with, and the ability to ask for advice to choose products or companies that meet a consumers needs are examples of this (Wattegama and Qing, 2014).

Companies have become aware of the importance of e-wom and increased their use of it for advertising as it is cheaper than traditional methods of advertisement and enables them to reach anyone, anywhere (Nair, Pinto, Chandran, Satheesh, 2017). Research shows that e-wom is considered important for organizations in marketing their products and services (Majali and Bohari, 2016).

The importance of this study lies in how people live in this fast changing world and adapt to the new, rapidly evolving, technology.

- This research may be useful for banks that have not yet activated mobile banking services to encourage them to embrace this technology and make plans for conducting mobile banking applications.

- Banks will be more interested to utilize apps in the future as everyone owns smart phones and prefer to make their transactions via applications. Long working hours and a desire to avoid long waiting period in banks, especially on days before holidays, drives customers to adopt mobile banking as a convenient alternative.

- The study will investigate how mobile banking applications affect e-wom and help companies retain their customers as well as increase their loyalty. Subsequently it will investigate the resulting good reputation and increase positive e-wom given by customers who want to be more involved in dealings with the bank.

\section{Problem Statement}

The banking sector has always been interested in using effective and new technology to provide the best services to their customers. After acceptance of internet banking, mobile banking has been utilized to complete numerous operations that customers need (Asfour and Haddad, 2014). The more that banks improve their services, the more people will talk about them on social media via e-wom. Discussions, media, and experiences are shared on online communities or pages on various social network sites where potential customers are able to see what others like (Phua, Jin, Kim, 2016). Mobile Characteristics have helped to expand the use of applications due to enhancement in transaction speed, decreasing costs and better service (Adewoye 2013)

This study investigates how customers use mobile banking applications and explores other factors such as ease of navigation, personalization, information quality, rewards (independent variables), and electronic word of mouth (dependent variables). It will study how these factors impact a customer's view of a company and how these services encourage customers to maintain a long relationship with banks, leaving them satisfied and wanting to talk about their experience with other potential customers. This study investigates how users accept mobile banking applications for performing transactions and how mobile banking applications effect e-wom when customers tell other people about the different kinds of services offered by the bank.

This study will attempt to answer the following questions:

1. Is there an effect of using mobile banking services on e-wom?

The following sub-questions will be considered: 
a) Is there an effect of ease of navigation on e-wom?

b) Is there an effect of personalization on e-wom?

c) Is there an effect of information quality on e-wom?

d) Is there an effect of rewards on e-wom?

\section{Research Objectives}

Purpose of this study is to reach the following objectives:

1. Test the effect of using mobile banking e-wom to:

a) Find the effect of ease of navigation in mobile banking applications on electronic word of mouth.

b) Test effect of personalization level in mobile banking application on e-wom.

c) Find out the effect of information quality in mobile banking applications on e-wom.

d) Test the effect of rewards in mobile banking applications on e-wom.

2. Test the effect of the mediating variable trust on the relationship between using mobile banking services on e-wom

\section{Operational Definition}

Ease of Navigation: In brief, includes both good formatting of the content layout as well as ease of use. And this variable can be measured by website accessibility, fast download, and language options (Hamid and McGrath's, 2005).

Personalization level: Adaptation of a service to fit the individual demands of a customer (Ball, Coelho, Vilares, 2006). The definitions found in a number of studies concur that personalization is the offer by a business to provide services that are adapted to the customer's needs. This variable can be measured by determining customer wants, attracting customers to services (Ball et al., 2006).

Information quality: is attaining information in a timely, clear, and easy manner and to keep the information correct (Jun and Cai, 2001).

Rewards: Are what you get for using a service or a prize you win for completing an action (Colin Pitts, 1995, p. 11.).This variable can be measured by reward quality and motivated rewards (Kirk \& Miller, 1986).

Perceived Trust: According to Mayer, Davis, and Schoorman (1995) as well as Rousseau, Sitkin, Burt, and Camerer (1998) is defined as a customer's ability to easily make bank transactions online and knowing that the customers need to believe in bank security will be met. This variable is measured by a customer's trust that the bank site will keep their information confidential (Ringle, Henseler, Sarstedt, 2014) (Kassim, 2017).

E-wom: is the use of internet to share experiences with other people through communities who are interested in a particular subject (Litvin, Goldsmith, Pan, 2008). Zikmund, Babin and Carr, (2010) state that this variable is measured by review recommendation, positive reviews and trusted e-wom.

\section{Literature Review}

\section{Theoretical Background}

This section will discuss the theoretical framework and investigate previous studies. It will highlight the definitions of information and communication technology (ICT), social media, electronic banking, mobile banking, e-wom and display related research studies. The main focus will be on the effect of using mobile banking applications on e-wom by the mediating role of perceived trust.

Information and communication technology (ICT) has become an important asset of managerial life in recent years. These kinds of technologies are being used in communication, decision support/production and office work (Al-Azzawi and Altmimi, 2015). Banks usually provide money into ICT applications for automating front and back offices. Despite the challenges of ICT, it remains an important matter in the banking sector with a rising need for the mutual benefit of banks and customers (Muhammad, Gatawa and Kebbi, 2014). According to Grigorian, Manole, (2002) Okereke and Nzotta, (2009) Thiel (2001) globalization has showed strong competition around the world within the banking sector. The world is now viewed as a global village which has lead to markets and economies being viewed in the same light.

According to Alawneh and Hattab (2009) research study where data was collected from 140 employees in seven major banks, using multiple liner regression, to estimate value of e-business at the bank scale in Jordan, e-banking had a positive effect on bank performance. According to Awamleh, Evans, Mahae, (2003) in the 
early days, only two banks conducted e-banking in Jordan, providing very few services online. Their websites were used to display the organization information, promotional information, branch locations, manager information, contact details and special news (Migdadi, 2008).

According to the researchers knowledge, there are not many studies on mobile banking service application variables (navigation, information quality, personalization level, rewards), particularly in Jordan. This study will investigate the effect of these variables on e-wom.

\section{Electronic banking}

Electronic banking (e-banking) is doing a bank transition such as you would perform in person within a branch, via the internet (Tavallaei, Shokouhyar, Pour, 2015). In order to make internet banking successful, the aim was to ensure efficacy and value of transactions. With the internet becoming a technology that everybody uses, big banks have created an internet banking system that is ready for companies to use and begin building a customer database (Salamah, 2017). E-banking has many advantages such as lower costs and ease of use via mobile and other electronic devices (Bello, 2010). To enhance customer loyalty, banks had to investigate new ways to retain their customer base and attract new customers (Al-Hawary, Hussien, 2017).

Alternative products have been created for customers due to increased competition in banking sector. Banks used different electronic channels to transfer their products and services for customer convenience and decreased cost. E-banking makes it easier for customers to get banking services at any time and place. E-banking is classified into three channels; Automatic teller machine (ATM), Internet banking (IB) and teller banking (George, Kumar, 2013). The banking sector in Jordan has been developed and treated as an essential aspect of the advanced economy, delivering electronic banking services to the customer, utilizing fast communication and cultivated information network security and comprehensiveness (Al-Hawary, et. al, 2017). Advantages of using e-banking include cost reduction, time saving, expansive customer reach, higher bank prestige through efficiency and services that meet customer gratification (Al-Fahim, 2013). According to Kujur, Shah (2015) e-banking introduced quicker, simpler and dependable services for customers, despite their uncertainty in security and inexperience in using e-banking application services.

\section{Mobile banking}

Banks have given attention to financial applications as a means of gaining a competitive advantage, creating effective customer relationship management (CRM) and facilitating decisions making in a timely, convenient way (Shaikh and Karjaluoto, 2013). When mobile banking was launched, customer usage rates were low, prompting managerial changes aimed at encouraging customers to switch to this technology. Efforts to enhance transactions along with the development of mobile devices as well as international economical strain were factors that lead to a speedy adoption of this technology (Asfour and Haddad, 2014).

According to Mwange (2011) mobile banking can enhance bank performance which raises market share and customer satisfaction. Mobile banking allows banks to extend products and services, personalize products and quickly respond to customer queries leading to improved customer retention as well as increase profit and decreased operational costs. According to Adewoye (2013) when banks provide new services through mobile banking, they are able to attract new customers as well as retain existing customers. The ability to promptly deal with customers helps to resolve and reduce complaints overall.

Four factors play a vital role when it comes to mobile banking; ease of navigation, personalization level, information quality and rewards. In 1992, Finland launched the first mobile banking application service, empowering customers by allowing them to do their financial activities on their mobile devices. Banks that intend to use m-banking services through mobile devices are required to follow the wireless service instructions (Al-Tarawneh, 2016).

Customers are increasingly able to rely on their bank association with services such as text alerts that notify a customer when they make a deposit, withdrawal or use credit cards and ATM cards. More advanced mobile banking services allow users to log into their accounts from mobile devices to make payments, check their account balance, transfer money between accounts, alert the bank of robbed credit cards, turn off payments on checks, change their security pin, display monthly statement and more (Jose, Kumar, Varghese, 2017).

Customers now expect to easily get service on demand through their mobile devices (Maroofi, Kahrarian, Dehghani, 2013). Studies show that 30\% of customers in United Kingdom use mobile banking (Agwu and Carter, 2014). Mobile banking is distinguished by its easy accessibility and user friendly interface, allowing customers to execute a variety of actions such as scanning invoices through their mobile camera or connecting to the stock market. Geo-location also helps to improve offers recommendation (Bondeson, Lindbom, 2018). 
According to Nicoletti (2014) it's a good opportunity for mobile banking to help customers perform their transactions in-front office application as they do in branches, ATMs, phone financial services, online financial services and more. There are numerous advantages with using mobile banking for small business, two of which being that it helps them give better services to old customers and reach new customers. Banks have been able to pass on their costs saving to customers by offering decreased monthly interest rates (Ammar, Ahmed, 2016).

\section{Ease of navigation}

Ease of use is the most fundamental aspect of using internet and mobile banking. It relates to how customers interact with a system and their willingness to accept it. It also alerts customers to new services (Al-Ghamdi, 2009). Research links ease of navigation to a customer's willingness to accept a new technology. Customer satisfaction depends on a website's or application's design fitting their desires (Fawzy and Esawai, 2017).

According to Amin, Onyeukwu and Osuagwu (2008), who tested the factors that result in an intention to use mobile banking through BIM bank, included that ease of navigation lead to the adoption of mobile banking. Ease of use is an important element to adjusting customers to use mobile banking applications and positively impacts customer intention to adopt it (Mashhour, Saleh, 2015). To avoid complications, it is important that it be easy to learn how to use mobile banking applications. Ease of navigation is considered one of driving elements for use of mobile banking (Alsamydai, Yassen, Alnaimi, Dajani, Qirem, 2014).

According to Islam, Salma (2016) ease of navigation effects the development and use of mobile banking application services. Ease of navigation can be measured by "internal control" (computer self-efficacy) and external control (facilitating conditions) into TAM (Kesharwani, Bisht, 2011). A complex interface that is difficult to navigate can delay customer adaptation, and result in customers being less willing to use the technology (Cudjoe, Anim, 2015).

\section{Personalization level}

According to Wessel and Thies (2015) the use of personalization features helps to provide products and services that are of particular value to individuals. Technological advances have allowed businesses to more accurately provide these individualized products and services, better meeting the needs and preferences of customers. The success of many website models has been largely dependent on personalization features due to the resulting customer satisfaction that comes with it (Wessel and Thies, 2015).

Attention to personalization is achieved by the method of collecting and analyzing data. Organizations can analyze every call and extract information in a systematic way (Berg, 2015, Tong, Australia, 2012). Using mobile banking application, banks can observe the preferences of their online customers in relation to a variety of subjects like weather, investments and hobbies. Customer will be able to control their finances by the use of personalized online financial planning tools (Nso, 2018). Personalized mobile banking application services can raise the capability and efficacy of active actions with mobile banking. Personalization level can help in evaluating the degree of customer satisfaction (Albashrawi, Motiwalla, 2015).

\section{Information quality}

According to English (1996), information quality is "consistently meeting customers' expectations, and through information and information services, enabling them to perform their job effectively". Information is the most important resource and because of that, different organizations depend on the quality of information. It allows organizations to make prediction which aid decision making.

Adopting of e-banking services has revolutionized the way banks interact with customer. The increased use of the internet has created a more informed population and this has heightened the expectations of customers (Ayyash, 2015).

Baskarada 2006; Ballou, Godwin, Shortridge., 2003 have found that through the use of the internet, information is easily accessible, abundant and reliable. Poor information quality causes problems and an unwanted crisis for businesses (Karagül and özdemir, 2012). To achieve customer satisfaction banks should consider providing information quality (Eshlaghy, Bayanati, 2013). When a business has a quality information system it increases the reliability of the system and encourages customers to use it (Ayyash, 2017). Customers select systems with high quality information to obtain value (Eshlaghy, Bayanati, 2013).

Types of information must be accredited and valid. Customers have a fear that banks may conceal relevant content from them, so it is important to eliminate inconsistency in information in order to gain customer confidence (Huili, Shanzhi, Yinghui, 2013). According to Al-Mamary, Shamsuddin and Aziati (2014) 
information should be relevant, understandable, accurate, brief, complete, on time and usable. Evaluating information quality demands a powerful base of information control including auditing, checking the state of information traits and constant enhancement to introduce acceptable active information systems (Alrayes, 2015). According to Chiguvi (2016), information quality effects customer loyalty, authenticity, sympathy, receptivity and positive certainty.

\section{Rewards}

"Reward is the benefits that arise from performing a task, rendering a service or discharging a responsibility." (Colin Pitts, 1995, p. 11.). Loyalty programs provide customers with a sensation of involvement and connection to the organization, leading to customer loyalty and satisfaction (Carvajal, Ruzzi, Nogales, Moreno, 2011). A reward program is when customers collect points, purchases or activity that allows them to earn free gifts, such as vouchers, discounts or gaining special memberships (Hamid, Cheng, Akhir, 2011). Rewards can be tangible (such as vouchers or discounts) or intangible (such as preferential treatment, elevated customer status) (Waarden, 2015).

\section{Perceived trust}

According to Mayer et al (1995) and Rousseau et al (1998) customer trust is a customer's willingness to do a banking transaction through the internet knowing that the bank will get it done, despite the customer's incapability to control or observe bank procedures. According to Fawzy and Esawai (2017), in Egypt, e-banking has not been fully adopted because of the perceived risk, thus customers are not confident to share their personal information and card details over internet.

Intention to trust means that customers accept to trust. Previous studies proved a positive relationship between intention to trust and trust (McKnight and Chervany, 2000; Kim and Benbasat, 2003). A customer's trust in the internet system has a significant impact in their desire to be involved in e-banking, online shopping, currency exchange and sharing their personal information (Mahad, Mohtar, Othman, 2015).

Trust in a bank and a customer's willingness to use e-banking is dependent on factors like a bank's reputation, web protection and smooth operation (Friedman, Kahn, \& Howe, 2000), (Munoz-Leiva, Luque-Martinez, \& Sanchez-Fernandez, 2010). The primary reason for using mobile banking services is to make customers secure and relaxed. Viruses that effect mobile devices increase customer anxiety about the safety of online payments, reducing their confidence in e-banking, affecting their behavior (Lafraxo, Hadri, Amhal, Rossafi, 2018).

Customers who recall a specific bank that provides mobile banking can affect how customers use mobile banking for the same bank (Wang and Chu Shan, 2013). Perceived trust is an essential element in order for customers to adjust to online banking (Sarfaraz, 2017).

\section{E-wom}

E-wom refers to customer expression in the past, present or future, which highlights favorable or unfavorable characteristics of products and services through an online community (Almana and Mirza, 2013). E-wom shares many similarities with traditional wom but its distinctive feature is that it is able to reach a vast audience (Almana and Mirza,2013).

E-wom appears on social media in a variety of ways. Customers can intentionally share information about brands, products and services without being paid. Or their interest in a brand can be displayed by them simply 'liking', commenting or being a member of a brand's page. Ad marketers also use social media, websites and accounts to post advertisements (Erkan and Evans, 2016).

Social networks including Facebook, LinkedIn, Twitter, Google, YouTube also provide different types of formats, like chat rooms, review sites and blogs that help spread e-wom (Senthilkumar, Ramachandran, 2013). E-wom is not limited by time or place which enhances its effectiveness and makes it the strongest path for marketing. However e-wom does not substitute traditional wom completely (Chen, 2011).

There are two types of online customers; customers who are diligent in posting their thoughts and opinions, and silent customer who read feedback from other customers (Alcocer, 2017). Information shared online is often written and can be published indefinitely, unlike traditional WOM. However, one of the downfalls of e-wom is that you can't always know who is sharing their opinion (Tantrabundit, 2018).

\section{Banking sector}

The banking sector in Jordan has been very stable with only a small number of banks exiting the market. There is good opportunity for growth, good capital and opportunities for external investors to enter the market (Ababneh, Wadi, Ismail, 2013). Jordan Ahli bank was the first bank to open in Jordan. It was established in 
1955 in Amman, with a starting capital of 350.000 Jordanian dinars (Taha, 2013). Since 2002, the banking sector in Jordan has sought to improve transactions on internet and mobile banking services (El-Qirem, 2013). Banks realized that in order to excel above others, it was necessary to provide e-banking services and encourage customers to use it in order to improve their transactions (Masoud, AbuTaqa, 2017).

\section{Previous studies:}

Study of Dineshwar and Steven (2013): the aim was to examine the acceptance of m-banking in Mauritius and how many people would use it, as well as factors that prevent or stimulate people in Mauritius to use it. Factors like suitability and time helped to encourage people to accept this technology. Lack of trust in mobile banking inhibited its spread. Results also showed that gender, age and salary did not impact mobile banking usage, however education did have an impact. This study recommended that local banks introduce mobile banking services in Mauritius.

Study of Al-Rfou, (2013) "The Usage of Internet Banking Evidence from Jordan" examined use of internet banking for commercial banks in Jordan from an e-service employee point of view. The finding was that there was a notable relationship between ease of use, security and privacy and quality of internet connection with usage of internet banking.

Study of Mohammad, Al-Tarawneh, (2014): "The Intermediate Effect of the Adoption of Electronic Banking Services between the Word of Mouth and the Quality of Banking Services" examined the effect of the use of word of mouth on the quality of banking services with intermediate variable adoption of e-banking services in commercial banks in Jordan. The finding was that there was a moderate degree of customers using word of mouth which showed that e-banking services in commercial banks in Jordan were average. Overall, word of mouth and adoption to e-banking services has had a good effect on quality of banking services.

Study of Burtch and Hong (2014): focused on the behavior of customers who used and did not use mobile banking as well as mobile features such as connection due to mobility. The research aim was to draw attention to location- based advertising and its relation to customer practice and gained content. They displayed a set of valuable dissimilarity of comments that are sent by mobile devices. It showed diversity in star rating. It also includes factual and impassioned text, which is considered useful. Association was directed to both service providers and online platforms management.

Study of Alsamydai et.,al, (2014): "The Factors Influencing Customer Usage Of Mobile Banking Services In Jordan" investigated aspects of the acceptance of the use of mobile banking services from customer opinion. The results showed that provided data demonstrated support of the conducted model.

Study of Alfina, Ero, Hidayanto, Shihab, (2014): “The Impact Of Cognitive Trust And e-wom On Purchase Intention In $\mathrm{C} 2 \mathrm{C}$ E-Commerce Site" developed a model to define the $\mathrm{C} 2 \mathrm{C}$ e-commerce environment, to determine what builds customer trust. The study used perceived trust and acceptance of e-wom information as well as an online questionnaire in kaskus format directed at the biggest online shopping community in Indonesia. The findings showed that trust positively effects purchase intention, and linked competency and transparency of the seller in relation to e-wom with an increase in customer trust.

Study of Alsheikh, Bojei, (2014): Aimed to detect elements that effect customer intention to accept mobile banking services in commercial banks in Saudi Arabia. The findings displayed that to understand technology functions and advantages depended on mobile experience and perceived attention. The recommendation was that if banks wanted to improve acceptance of mobile banking they needed to provide creative services that were unique to e-banking in order to compete with other banking services.

Study of Kachembere and Choga (2015): The aim was is to study the impact of e-marketing on commercial banks for a period of 20 years. The study examined the acceptance of e-marketing services in commercial banks. The variables that are measured in the study were ease of use, usefulness, perceived cost and trust. The findings of the study indicated that useful, ease of use and acceptance rate of e-marketing services were high. The aspects that caused customer fear included uncertainty of extent reliability, electronic channels, the banks themselves, network providers and infrastructure. The recommendation of the researcher was to increase interaction with customers as well as to increase involvement in customer account needs.

Study of ElAziz, ElBadrawy and Hussien (2015): “ATM, Internet Banking and Mobile Banking Services in a Digital Environment: The Egyptian Banking Industry" aimed to discover the factors that affect customer intention to use self-service banking technologies in Egypt. The findings showed there was a significant difference between the three groups in relation to usage, value, risk, tradition and image.

Study of Mehrad and Mohammadi (2016): examined the effect of e-wom on acceptance of mobile banking in 
Iran. It presents how some factors effect adjustment to mobile banking services. Results showed that the primary factor that effected user attitude toward mobile banking is word of mouth. They agree that positive affect of WOM influences other factors on the acceptance of mobile banking. Most of the research gave attention to a number of factors working on the acceptance of mobile banking, but not many of them gave any attention to word of mouth in iran.

The study of Zhao, Liu, Lai, Zhang. H. and Zhang, Y., (2016): Showed that with all new technologies, social networking sites enabled people to contact others easily and gave them the ability to share information through wireless connection and smart-phones. Social network sites have evolved with the evolution of mobile devices, creating many new applications and attracting an increase in the number of users. The findings displayed how mobile sensor computing industry aid to establish powerful strategies and form sustainable user relationship.

\section{Research model}

Based on thorough literature review related to electronic word of mouth theories and practices through social networking sites; the researcher suggested this conceptual model to define and establish the relationships between the research variable:

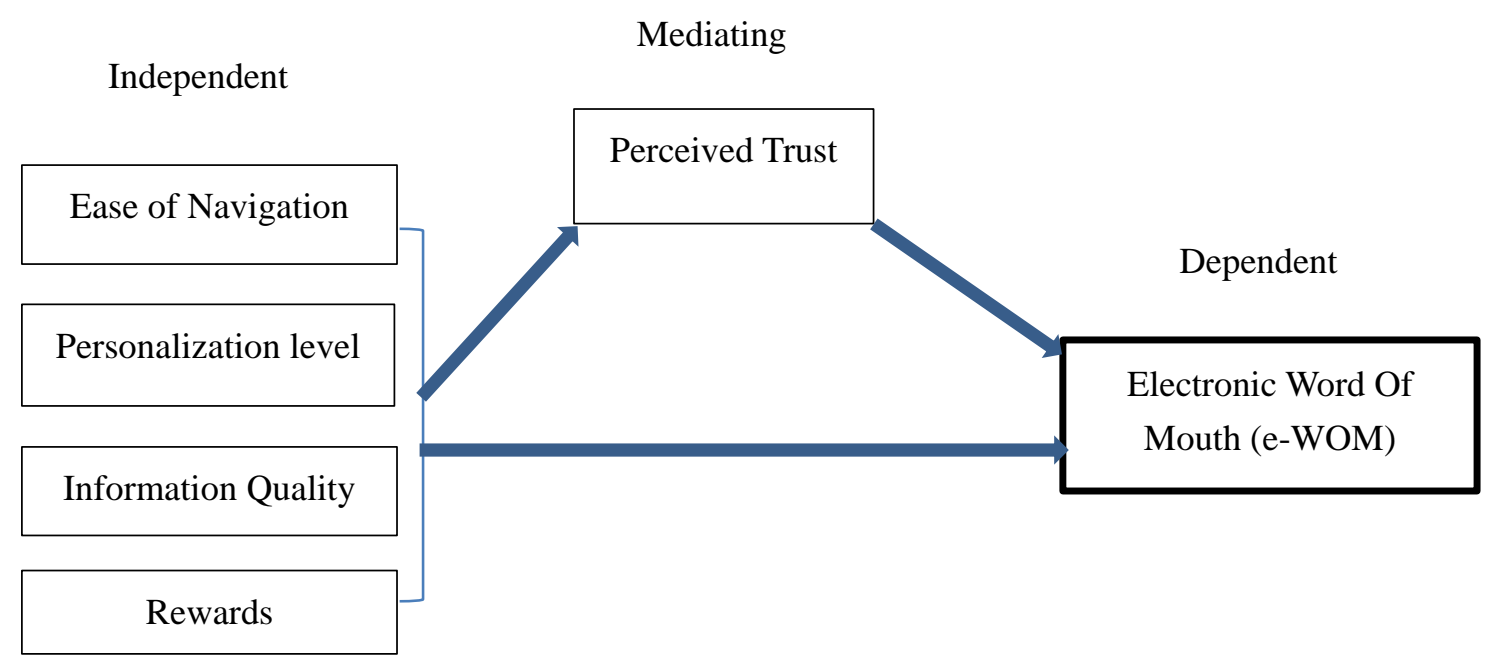

Figure 1. Proposed Research Model

Adapted from (Senthilkumar et al., 2013, Hamid et al 2011; Montazemi, Saremi, 2014)

\section{Research hypotheses:}

H01: there is no effect of ease of navigation on electronic word of mouth at $\mathrm{a} \leq(0.05)$.

H02: There is no effect of personalization level on electronic word of mouth at $\mathrm{a} \leq(0.05)$.

H03: There is no effect of information quality on electronic word of mouth at a $\leq(0.05)$.

H04: There is no effect of rewards on electronic word of mouth at $\mathrm{a} \leq(0.05)$.

H05: There is no effect of ease of navigation, personalization level, information quality, and rewards on electronic word of mouth through perceived trust at $\mathrm{a} \leq(0.05)$.

\section{Research Methodology}

Research methodology contains the research design, approach and methods that are used in the study. Collection of data, data processing and analyzing techniques that help to examine the effect of using mobile banking application services on electronic word of mouth.

The research used quantitative technique and both descriptive and analytical method. A research questionnaire was used and distributed to 551, of which 469 were returned and accepted. 


\section{Results and Discussions}

Table 1a. the mean standard deviation and level of significance of the research variables

\begin{tabular}{|c|c|c|c|c|}
\hline \multicolumn{5}{|c|}{ Descriptive Statistics } \\
\hline & Mean & Std. Deviation & Analysis $N$ & level \\
\hline \multicolumn{5}{|c|}{ Independent Variables } \\
\hline \multicolumn{5}{|c|}{ Ease of Navigation } \\
\hline$Q 1$ & 4.73 & 0.566 & 469 & high \\
\hline$Q 2$ & 4.62 & 0.586 & 469 & high \\
\hline$Q 3$ & 4.58 & 0.614 & 469 & high \\
\hline$Q 4$ & 4.54 & 0.661 & 469 & high \\
\hline$Q 5$ & 4.49 & 0.694 & 469 & high \\
\hline$Q 6$ & 4.60 & 0.628 & 469 & high \\
\hline All & 4.5928 & 0.50553 & 469 & high \\
\hline \multicolumn{5}{|c|}{ Information Ouality } \\
\hline$Q 7$ & 4.33 & 0.695 & 469 & high \\
\hline$Q 8$ & 4.25 & 0.899 & 469 & high \\
\hline$Q^{9}$ & 4.50 & 0.665 & 469 & high \\
\hline$Q 10$ & 4.56 & 0.679 & 469 & high \\
\hline$Q 11$ & 4.55 & 0.725 & 469 & high \\
\hline Q12 & 4.53 & 0.807 & 469 & high \\
\hline All & 4.4542 & 0.56831 & 469 & high \\
\hline \multicolumn{5}{|c|}{ Personalization Level } \\
\hline$Q 13$ & 4.32 & 0.663 & 469 & high \\
\hline$Q 14$ & 4.20 & 0.889 & 469 & high \\
\hline$Q 15$ & 2.30 & 1.267 & 469 & Low \\
\hline Q16 & 2.89 & 1.395 & 469 & Moderate \\
\hline Q17 & 2.27 & 1.229 & 469 & Low \\
\hline All & 3.1962 & 0.68941 & 469 & Moderate \\
\hline \multicolumn{5}{|c|}{ Rewards } \\
\hline Q18 & 2.77 & 1.323 & 469 & V.Low \\
\hline Q19 & 2.10 & 1.176 & 469 & Low \\
\hline$Q 20$ & 1.89 & 1.054 & 469 & Low \\
\hline$O 21$ & 2.42 & 1.280 & 469 & Low \\
\hline O22 & 2.06 & 1.152 & 469 & Low \\
\hline All & 2.2486 & 0.92535 & 469 & Low \\
\hline \multicolumn{5}{|c|}{ Mediator Variable } \\
\hline \multicolumn{5}{|c|}{ Perceived Trust } \\
\hline$Q 23$ & 3.93 & 0.932 & 469 & high \\
\hline$Q 24$ & 4.12 & 1.055 & 469 & high \\
\hline$Q 25$ & 4.23 & 1.035 & 469 & V,high \\
\hline$Q 26$ & 4.47 & 0.888 & 469 & V.high \\
\hline$Q 27$ & 4.28 & 1.094 & 469 & V.high \\
\hline All & 4.2055 & 0.86975 & 469 & V.high \\
\hline \multicolumn{5}{|c|}{ Dependent Variable } \\
\hline$e$-won & & & & \\
\hline$Q 28$ & 4.18 & 0.890 & 469 & high \\
\hline$Q 29$ & 4.38 & 0.890 & 469 & high \\
\hline$Q 30$ & 4.27 & 0.955 & 469 & V,high \\
\hline$Q 31$ & 4.39 & 0.938 & 469 & V.high \\
\hline$Q 32$ & 4.37 & 0.954 & 469 & V.high \\
\hline All & 4.3190 & 0.74197 & 469 & V.high \\
\hline
\end{tabular}

Table 1a shows the following:

- There is a statistically significant effect for ease of navigation on electronic word of mouth through perceived trust.

- There is a statistically significant effect for personalization level on electronic word of mouth through perceived trust.

- $\quad$ There is a statistically significant effect for information Quality on electronic word of mouth through perceived trust.

- There is a significant mediation role for Perceived Trust in the effect of Rewards on e-wom.

The results of the study showed that there was a significant effect mediation role in the ease of navigation, personalization level, information quality, rewards on e-wom through perceived trust for users of mobile banking 
in Jordan. It showed that there is a necessity to increase the comfort zone of the user of mobile banking services applications in order to gain more value in completing their transactions as quickly as possible with less effort and cost.

In comparing the results of the study with other similar studies such as (Harelimana,2017) study which showed that mobile banking had a positive effect on financial performance of Unguka Bank Ltd. Mobile banking products like bill payment increased profit through the commissions gained from customers, showing that using mobile banking is more effective than traditional banking services. However some services such as account transfer, account statement, mobile money and book check order are not yet active enough. In the study of (Javabdeh, Ahmad, 2014) they examined two important aspects in mobile banking security in relation to customer trust, loyalty and positive WOM. Results showed a direct and significant relationship between trust and WOM finding a direct and significant relationship between trust and loyalty.

\section{Data Analysis}

To analyze the data collected from the respondents who answered the questionnaire, SPSS application is used, applying the following tests: reliability analysis and descriptive statistics and regression process.

\section{Reliability Analysis:}

Table $1 \mathrm{~b}$ shows the Cronbach's alpha test value is equal to 0.853 . That means that the items have relatively high internal consistency. The reliability coefficient of 0.70 or higher is considered "acceptable" in the majority social science research.

Table 1b. Cronbach Alpha Results

\begin{tabular}{cccccccc}
\hline & $\begin{array}{c}\text { Ease of } \\
\text { Navigation }\end{array}$ & $\begin{array}{c}\text { Information } \\
\text { Quality }\end{array}$ & $\begin{array}{c}\text { Personalization } \\
\text { Level }\end{array}$ & Rewards & $\begin{array}{c}\text { Perceived } \\
\text { Trust }\end{array}$ & e-wom & All Variables \\
\hline No. of items & 6 & 6 & 5 & 5 & 5 & 5 & 32 \\
Cronbach's Alpha & 0.893 & 0.852 & 0.752 & 0.829 & 0.917 & 0.861 & 0.853 \\
\hline
\end{tabular}

\section{Descriptive statistics}

Table 2. Cross Tabulation Statistics for demographic questions

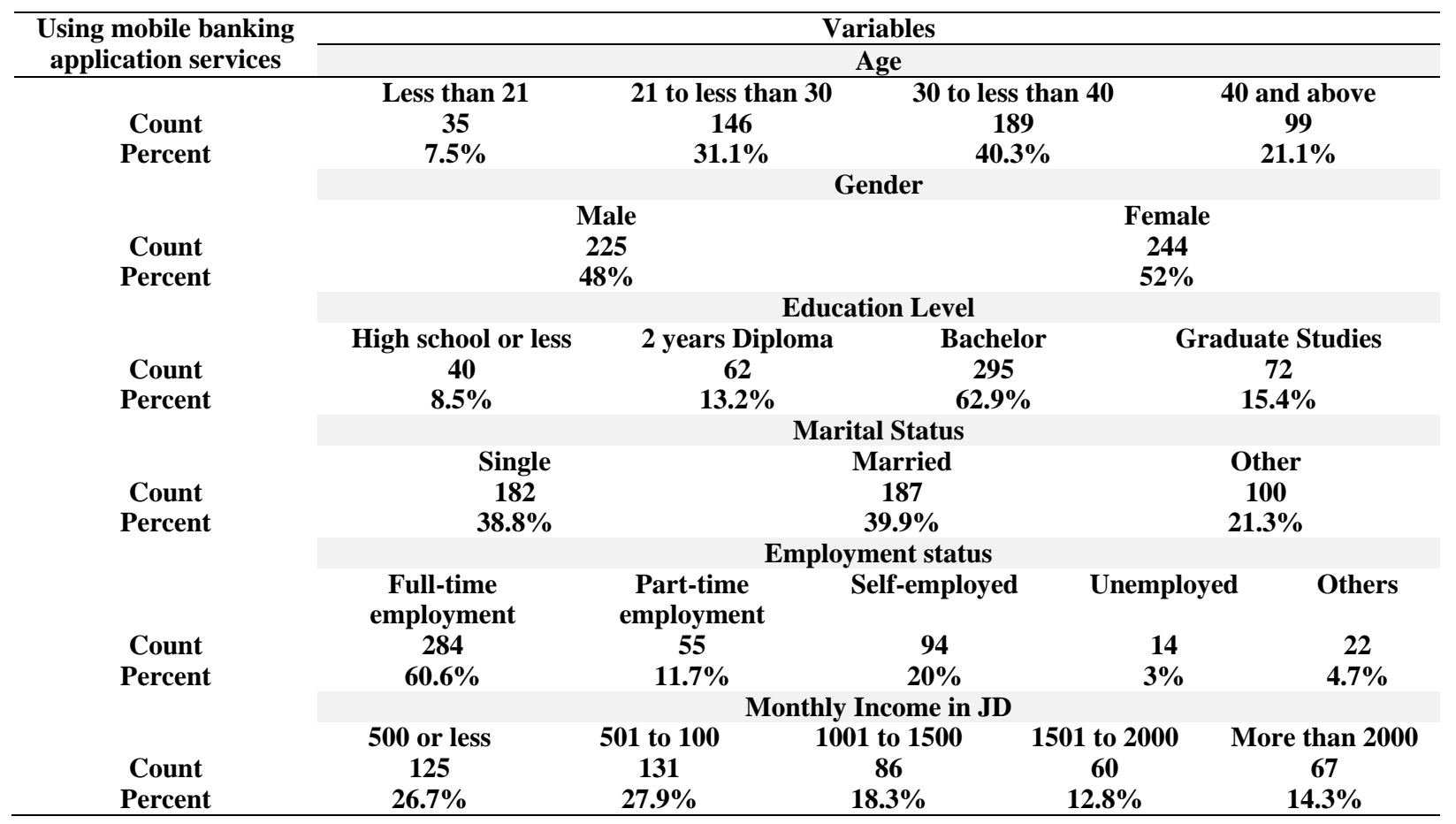

Table 2 shows:

$79 \%$ of the respondents are less than 40 years old, 52\% are females, $63 \%$ are bachelor degree holders, $40 \%$ are married, $61 \%$ have full time employment and $73 \%$ have an income of less than 1500JD. 
1) Descriptive statistics for $Q 1$ to Q32:

Table 3. Descriptive Statistics for Q1 to Q50

\begin{tabular}{|c|c|c|c|}
\hline \multicolumn{4}{|c|}{ Descriptive Statistics } \\
\hline & Mean & Std. Deviation & Analysis $N$ \\
\hline \multicolumn{4}{|c|}{ Independent Variables } \\
\hline \multicolumn{4}{|c|}{ Ease of Navigation } \\
\hline$Q 1$ & 4.73 & 0.566 & High \\
\hline$Q^{2}$ & 4.62 & 0.586 & High \\
\hline$Q 3$ & 4.58 & 0.614 & High \\
\hline$Q^{4}$ & 4.54 & 0.661 & High \\
\hline Q5 & 4.49 & 0.694 & High \\
\hline Q6 & 4.60 & 0.628 & High \\
\hline All & 4.5928 & 0.50553 & High \\
\hline \multicolumn{4}{|c|}{ Information Quality } \\
\hline$Q 7$ & 4.33 & 0.695 & High \\
\hline$Q 8$ & 4.25 & 0.899 & High \\
\hline$Q^{9}$ & 4.50 & 0.665 & High \\
\hline$Q 10$ & 4.56 & 0.679 & High \\
\hline$Q 11$ & 4.55 & 0.725 & High \\
\hline$Q 12$ & 4.53 & 0.807 & High \\
\hline All & 4.4542 & 0.56831 & High \\
\hline \multicolumn{4}{|c|}{ Personalization Level } \\
\hline$Q 13$ & 4.32 & 0.663 & High \\
\hline$Q 14$ & 4.20 & 0.889 & High \\
\hline$Q 15$ & 2.30 & 1.267 & Low \\
\hline$Q 16$ & 2.89 & 1.395 & Low \\
\hline$Q 17$ & 2.27 & 1.229 & Low \\
\hline All & 3.1962 & 0.68941 & Medium \\
\hline \multicolumn{4}{|c|}{ Rewards } \\
\hline$Q 18$ & 2.77 & 1.323 & Low \\
\hline$Q 19$ & 2.10 & 1.176 & Low \\
\hline$Q 20$ & 1.89 & 1.054 & Low \\
\hline$Q 21$ & 2.42 & 1.280 & Low \\
\hline$Q 22$ & 2.06 & 1.152 & Low \\
\hline All & 2.2486 & 0.92535 & Low \\
\hline \multicolumn{4}{|c|}{ Mediator Variable } \\
\hline \multicolumn{4}{|c|}{ Perceived Trust } \\
\hline$Q 23$ & 3.93 & 0.932 & Medium \\
\hline$Q 24$ & 4.12 & 1.055 & High \\
\hline$Q 25$ & 4.23 & 1.035 & High \\
\hline$Q 26$ & 4.47 & 0.888 & High \\
\hline$Q 27$ & 4.28 & 1.094 & High \\
\hline All & 4.2055 & 0.86975 & High \\
\hline \multicolumn{4}{|c|}{ Dependent Variable } \\
\hline \multicolumn{4}{|c|}{ e-wom } \\
\hline$Q 28$ & 4.18 & 0.890 & High \\
\hline$Q 29$ & 4.38 & 0.890 & High \\
\hline$Q 30$ & 4.27 & 0.955 & High \\
\hline$Q 31$ & 4.39 & 0.938 & High \\
\hline$Q 32$ & 4.37 & 0.954 & High \\
\hline All & 4.3190 & 0.74197 & High \\
\hline
\end{tabular}

For the purpose of the analysis, 4.0 and above is considered high, 3.0-3.99 is considered medium, and below 3.0 is low. Table 3 indicates that respondents answer for ease of navigation, information quality, perceived trust and e-wom are high, while personalization level is moderate and rewards is low.

\section{Testing of validity}

The questionnaire was given to a group of experts to investigate the set of questions and show their remarks on their relevancy to the researcher problem. All notices are taken in account and the questionnaire reproduced accordingly.

\section{Test of multicollinearity}


Table 4. shows the results of multicollinearity using the variance inflation factor (VIF)

Test of Multicollinearity

\begin{tabular}{lc}
\hline & Variance Inflation Factors(VIF) \\
\hline Ease of Navigation & 1.549 \\
Information Quality & 1.666 \\
Personalization Level & 2.380 \\
Rewards & 1.089 \\
Perceived Trust & 1.671 \\
\hline
\end{tabular}

The obtained VIF values in Table 4 test the severity of the multicollinearity problem, is between 1 and 10 , meaning that there is no multicollinearity which indicates that there is no correlation between predictors (independent variables) in the model, so the model is valid to use regression process test.

\section{Testing Hypothesis}

a- First Hypothesis:

$\mathrm{H}_{01}$ : There is no statistically significant effect of ease of navigation on e-wom through perceived trust at $\mathbf{a} \leq \mathbf{( 0 . 0 5 )}$.

Table 5. Test of H01 results

\begin{tabular}{|c|c|c|c|c|c|c|c|c|}
\hline Model & $\begin{array}{c}\text { Independent } \\
\text { Variable } \\
\end{array}$ & $\begin{array}{c}\begin{array}{c}\text { Correlation } \\
(\mathbf{R})\end{array} \\
\end{array}$ & $\begin{array}{c}(\beta) \\
\text { Value } \\
\end{array}$ & $\begin{array}{c}\mathbf{t} \\
\text { value }\end{array}$ & Sig. $\mathbf{t}$ & $\begin{array}{c}\mathbf{F} \\
\text { value }\end{array}$ & $\begin{array}{l}p \text {-value } \\
\text { Sig. F }\end{array}$ & $\begin{array}{c}\text { Hypothesis } \\
\text { Support }\end{array}$ \\
\hline Model1 & Ease of Navigation & $\begin{array}{c}\mathbf{0 . 3 9 7 2} \\
\text { Sig. }=0.000 \\
\end{array}$ & 0.5830 & 9.3529 & 0.000 & 87.4768 & 0.000 & \\
\hline \multirow[t]{2}{*}{ Model2 } & Ease of Navigation & \multirow{2}{*}{$\begin{array}{c}0.6497 \\
\text { Sig. }=0.000\end{array}$} & 0.3789 & 7.0760 & 0.000 & & & \multirow{2}{*}{$\begin{array}{c}\text { Reject } \\
\mathbf{H}_{01}\end{array}$} \\
\hline & $\begin{array}{c}\text { Mediator } \\
\text { Perceived Trust }\end{array}$ & & 0.4544 & 14.5999 & 0.000 & 170.187 & 0.000 & \\
\hline \multicolumn{9}{|c|}{ Model1 $\left(R^{2}=0.1578\right)$, Model2 $\left(R^{2}=0.4221, R^{2}\right.$ changed $\left.=0.2643\right)$} \\
\hline
\end{tabular}

Table 5 shows that the direct relationship between the independent variable Ease of Navigation and the dependent variable e-wom in the model is a medium positive significant relationship where the value of person correlation was equal to (0.397), but the relationship between the two variables through the existing of the mediator variable Perceived Trust increased in Model 2 to 0.6497, indicating to a strong positive significant relationship.

There is a significant mediation role for Perceived Trust in the effect of Ease of Navigation on e-wom.

$\mathrm{H}_{02}$ : There is no statistically significant effect of Personalization Level on e-wom through perceived trust at $\mathbf{a} \leq(\mathbf{0 . 0 5})$.

Table 6. Test of $\mathrm{H} 02$ results

\begin{tabular}{|c|c|c|c|c|c|c|c|c|}
\hline Model & $\begin{array}{c}\text { Independent } \\
\text { Variable }\end{array}$ & $\begin{array}{l}\text { Correlation } \\
\text { (R) }\end{array}$ & $\begin{array}{c}(\beta) \\
\text { Value }\end{array}$ & $\begin{array}{c}\mathbf{t} \\
\text { value }\end{array}$ & Sig. $t$ & $\underset{\text { value }}{\mathbf{F}}$ & $\begin{array}{l}p \text {-value } \\
\text { Sig. F }\end{array}$ & $\begin{array}{c}\text { Hypothesis } \\
\text { Support }\end{array}$ \\
\hline Model1 & $\begin{array}{c}\text { Personalization } \\
\text { Level }\end{array}$ & $\begin{array}{c}0.0487 \\
\text { Sig. }=0.2923\end{array}$ & -0.0524 & -1.0543 & 0.292 & 1.1116 & 0.2923 & \\
\hline \multirow[b]{2}{*}{ Model2 } & $\begin{array}{c}\text { Personalization } \\
\text { Level }\end{array}$ & \multirow[b]{2}{*}{$\begin{array}{c}0.6070 \\
\text { Sig. }=0.000\end{array}$} & -0.0993 & -2.4994 & 0.012 & \multirow[b]{2}{*}{135.950} & \multirow[b]{2}{*}{0.000} & \multirow[b]{2}{*}{$\begin{array}{c}\text { Reject } \\
\mathbf{H}_{02}\end{array}$} \\
\hline & $\begin{array}{c}\text { Mediating } \\
\text { variable } \\
\text { Perceived Trust }\end{array}$ & & 0.5175 & 16.4362 & 0.000 & & & \\
\hline & & $\left(R^{2}=0.00\right.$ & odel & 3685 & n & 3661) & & \\
\hline
\end{tabular}


Table 6 shows that the direct relationship between the independent variable Personalization Level and the dependent variable e-wom in Model 1 was a very weak, insignificant relationship where the value of person correlation was equal to (0.0487), but the relationship between the two variables through the existing of the mediating variable Perceived Trust increased in Model 2 to 0.6070, indicating to a strong positive significant relationship.

There is a significant mediation role for Perceived Trust in the effect of Personalization Level on e-wom.

$H_{03}$ : There is no statistically significant effect of Information Quality on e-wom through perceived trust at $\mathrm{a} \leq(\mathbf{0 . 0 5})$.

Table 7. Test of H03 results

\begin{tabular}{|c|c|c|c|c|c|c|c|c|}
\hline Model & $\begin{array}{c}\text { Independent } \\
\text { Variable }\end{array}$ & $\begin{array}{c}\text { Correlation } \\
(\mathbf{R})\end{array}$ & $\begin{array}{c}(\boldsymbol{\beta}) \\
\text { Value }\end{array}$ & $\begin{array}{c}\mathbf{t} \\
\text { value }\end{array}$ & Sig.t & $\begin{array}{c}\mathbf{F} \\
\text { value }\end{array}$ & $\begin{array}{c}p \text {-value } \\
\text { Sig. F }\end{array}$ & $\begin{array}{c}\text { Hypothesis } \\
\text { Support }\end{array}$ \\
\hline Model1 & $\begin{array}{c}\text { Information } \\
\text { Quality }\end{array}$ & $\begin{array}{c}0.3876 \\
\text { Sig. }=0.2923\end{array}$ & 0.5061 & 9.0867 & 0.292 & 82.5683 & 0.000 & \\
\hline \multirow{2}{*}{ Model2 } & $\begin{array}{c}\text { Information } \\
\text { Quality }\end{array}$ & \multirow{2}{*}{$\begin{array}{c}0.6472 \\
\text { Sig. }=0.000\end{array}$} & 0.3275 & 6.8684 & 0.000 & \multirow{2}{*}{167.926} & \multirow[t]{2}{*}{$\mathbf{0 . 0 0 0}$} & \multirow[t]{2}{*}{$\begin{array}{c}\text { Reject } \\
\mathbf{H}_{03}\end{array}$} \\
\hline & $\begin{array}{c}\text { Mediator } \\
\text { Perceived Trust }\end{array}$ & & 0.4573 & 14.6758 & 0.000 & & & \\
\hline
\end{tabular}

Table 7 shows that the direct relationship between the independent variable Information Quality and the dependent variable e-wom in Model 1 was a medium positive significant relationship where the value of person correlation was equal to (0.3876), but the relationship between the two variables through the existing of the mediator variable Perceived Trust increased in Model2 to 0.6472, indicating to a strong positive significant relationship.

There is a significant mediation role for Perceived Trust in the effect of Information Quality on e-wom.

$\mathrm{H}_{04}$ : There is no statistically significant effect of Rewards on e-wom through perceived trust at a $\leq(\mathbf{0 . 0 5})$.

Table 8. Test of H04 results

\begin{tabular}{|c|c|c|c|c|c|c|c|c|}
\hline Model & $\begin{array}{l}\text { Independent } \\
\text { Variable }\end{array}$ & $\begin{array}{c}\text { Correlation } \\
\text { (R) }\end{array}$ & $\begin{array}{c}(\beta) \\
\text { Value }\end{array}$ & $\begin{array}{c}\mathrm{t} \\
\text { value }\end{array}$ & Sig. $t$ & $\begin{array}{c}\text { F } \\
\text { value }\end{array}$ & $\begin{array}{c}p \text {-value } \\
\text { Sig. F }\end{array}$ & $\begin{array}{c}\text { Hypothesis } \\
\text { Support }\end{array}$ \\
\hline Model1 & Rewards & $\begin{array}{c}0.0094 \\
\text { Sig. }=0.8385\end{array}$ & -0.0076 & -0.2040 & 0.838 & 0.0416 & 0.8385 & \\
\hline \multirow[b]{2}{*}{ Model2 } & Rewards & \multirow{2}{*}{$\begin{array}{c}\mathbf{0 . 6 0 7 0} \\
\text { Sig. }=\mathbf{0 . 0 0 0}\end{array}$} & -0.0572 & -1.9226 & 0.012 & \multirow[b]{2}{*}{133.957} & \multirow[b]{2}{*}{0.000} & \multirow{2}{*}{$\begin{array}{c}\text { Reject } \\
\mathbf{H}_{04}\end{array}$} \\
\hline & $\begin{array}{c}\text { Mediator } \\
\text { Perceived Trust }\end{array}$ & & 0.5181 & 16.3661 & 0.000 & & & \\
\hline
\end{tabular}

Table 8 shows that the direct relationship between the independent variable Rewards and the dependent variable e-wom in Model 1 was a very weak, insignificant relationship where the value of person correlation was equal to (0.0094), but the relationship between the two variables through the existing of the mediator variable Perceived Trust increased in Model2 to 0.6042, indicating to a strong positive significant relationship.

There is a significant mediation role for Perceived Trust in the effect of Rewards on e-wom. 


\section{Conclusion and Recommendation}

The research shows that there is a statistically significant effect of ease of navigation, personalization, information quality and rewards on e-wom. Perceived trust as a mediating variable was found to be significant in the impact of relationship between independent variables (ease of navigation, personalization, information quality and rewards) on the dependant variable (e-wom).

It is recommended that banks need to increase the comfort zone for the users of mobile banking service applications in order to gain more value in completing their transactions as quickly as possible with less effort and cost. More attention must be given to personalization level and rewards in e-banking in order to improve them and become more involved with customers so as to encourage them to use this technology. These factors can be adopted in future research in other countries to assist them in measuring their impact in other environments.

\section{References}

Ab Hamid, N., \& McGrath, M. (2005). The Diffusion of Internet Interactivity on Retail Web Sites: A Customer Relationship Model. Retrieved from https://scholarworks.lib.csusb.edu/ciima/vol5/iss2/4

Ab Hamid, N., Cheng, A., \& Akhir, R. (2011). Dimensions of E-CRM:An Empirical Study on Hotels' Web Site. https://doi.org/10.5171/2011.820820

Ababneh, F., Al Wadi, S., \& Ismail, M. (2013). Haar and Daubechies Wavelet Methods in Modeling Banking Sector. https://doi.org/10.12988/imf.2013.13056

Adewoye, J. O. (2013). Impact of Mobile Banking on Service Delivery in the Nigerian Commercial Banks. International Review of Management and Business Research, 2. Retrieved from http://irmbrjournal.com/papers/1371450683.pdf

Agwu, E., \& Carter, A. (2014). Mobile Phone Banking In Nigeria: Benefits, Problems and Prospects. International Journal of Business and Commerce. Retrieved from http://ijbcnet.com/3-6/IJBC-14-3608.pdf

Alalwan, A., Dwivedi, Y., Rana, N., Lal, B., \& Williams, M. (2015). Consumer adoption of Internet banking in Jordan: Examining the role of hedonic motivation, habit, self-efficacy and trust. https://doi.org/10.1057/fsm.2015.5

Alawneh, A., \& Hattab, E. (2009). An Empirical Study of Sources Affecting E-Business Value Creation in Jordanian Banking Services Sector. International Arab Journal of e-Technology, 1(2). https://doi.org/10.4018/jantti.2009040104

Al-Azzawi, A., \& Altmimi, L. (2015). Effect of Information and Communication Technology Investment on the Profitability of the Jordanian Commercial Banks. European Journal of Business and Management, 7. Retrieved from https://www.iiste.org/Journals/index.php/EJBM/article/view/26829

Albashrawi, M., \& Motiwalla, L. (2015). The Moderating Effect of Privacy and Personalization in Mobile Banking: A Structural Equation Modeling Analysis. Twenty-first Americas Conference on Information Systems, Puerto Rico. Retrieved from

https://aisel.aisnet.org/cgi/viewcontent.cgi?referer=\&httpsredir=1\&article=1509\&context=amcis 2015

Alcocer, N. (2017). A Literature Review of Word of Mouth and Electronic Word of Mouth: Implications for Consumer Behavior.

Al-Fahim, N. (2013). An Exploratory Study of Factors Affecting the Internet Banking Adoption: A Qualitative Study among Postgraduate Students. Global Journal of Management and Business Research Finance, 13(8). Retrieved from https://globaljournals.org/GJMBR_Volume13/3-An-Exploratory-Study-of-Factors.pdf

Alfina, I., Ero, J., Hidayanto, A., \& Shihab, M. (2014). The Impact Of Cognitive Trust And E-Wom On Purchase Intention In C2c E-Commerce Site. https://doi.org/10.3844/jcssp.2014.2518.2524

Al-Ghamdi, A. (2009). Investigating Factors Affecting Customers of Using Internet Banking: A Comparison study between Saudi Arabia and the UK. Brunel Business School, Doctoral Symposium. Retrieved from https://www.brunel.ac.uk/_data/assets/file/0005/90635/phdSimp2009AbdullahALGhamdi.pdf

Al-Hawary, S., \& Hussien, A. (2017). The Impact of Electronic Banking Services on the Customers Loyalty of Commercial Banks in Jordan. International Journal of Academic Research in Accounting, Finance and Management Sciences, 7(1). https://doi.org/10.6007/IJARAFMS/v7-i1/2539

AlKailani, M. (2016). Factors Affecting the Adoption of Internet Banking in Jordan:An Extended TAM Model. 
https://doi.org/10.1108/IJBM-03-2014-0043

Al-Mamary, Y., Shamsuddin, A., \& Aziati, N. (2014). The Relationship between System Quality, Information Quality, and Organizational Performance. International Journal of Knowledge and Research in Management \& E-Commerce, 4(3), July, 2014. Retrieved from https://pdfs.semanticscholar.org/3518/55bbdaf7c5ee5aed18a92fb8a91beca39d1e.pdf

Almana, A., \& Mirza, A. (2013). The Effect of Electronic Word of Mouth on Consumers' Purchasing Decisions.

Al-Rfou, A. (2013). The Usage of Internet Banking Evidence from Jordan. Asian Economic and Financial Review. Retrieved from

https://www.researchgate.net/publication/299597666_The_Usage_of_Internet_Banking_-_Evidence_from_ Jordan

Alsamydai, M., Yassen, S., Alnaimi, H., Dajani, D., \& Qirem, I. (2014). The Factors Influencing Customer Usage Of Mobile Banking Services In Jordan. International Journal of Business Management \& Research. Retrieved from https://www.zuj.edu.jo/wp-content/staff-research/economic/dr.saad-yaseen/7.pdf

Alsheikh, L., \& Bojei, J. (2014). Determinants Affecting Customer's Intention to Adopt Mobile Banking in Saudi Arabia. International Arab Journal of e-Technology, 3(4), June 2014.

Al-Tarawneh, J. (2016). Factors influencing the adoption of Mobile banking services in Jordan from the perspective of customers: Overview and Pilot study. International Journal of Scientific and Research Publications, 6(9). Retrieved from http://www.ijsrp.org/research-paper-0916/ijsrp-p5727.pdf

Amin, H., Onyeukwu, P., \& Osuagwu, H. (2018). E - Banking, Service Quality and Customer Satisfaction in Selected Nigerian Banks. https://doi.org/10.18775/ijied.1849-7551-7020.2015.42.2004

Ammar, A., \& Ahmed, E. (2016). Factors influencing Sudanese microfinance intention to adopt mobile banking. https://doi.org/10.1080/23311975.2016.1154257

Anton, G. (2014). The Effect of Internet Banking On The Use Of Banking Services. http://www.kse.org.ua/download.php?downloadid=390

Asfour, H., \& Haddad, S. (2014). The Effect of Mobile Banking on Enhancing Customers' E-Satisfaction: An Empirical Study on Commercial Banks in Jordan. https://doi.org/10.5539/ibr.v7n10p145

Awamleh, R., Evans, J., \& Mahae, A. (2003). Internet Banking in Emergency Markets The Case of Jordon. Journal of Internet Banking and Commerce, 8(1). Retrieved from

http://www.icommercecentral.com/open-access/internet-banking-in-emergency-markets-the-case-of-jordona-note.pdf

Ayyash, M. (2015). Identifying Information Quality Dimensions That Affect Customers Satisfaction of Ebanking Services. Journal of Theoretical and Applied Information Technology. Retrieved from https://www.researchgate.net/publication/288436876_Identifying_information_quality_dimensions_that_aff ect_customers_satisfaction_of_e-banking_services

Ayyash, M. (2017). Scrutiny of Relationship between E-Banking Information Quality Dimensions and Customer Satisfaction. https://doi.org/10.3844/jcssp.2017.78.90

Bagudu, H., Khan, S., \& Roslan, A. (2017). The Effect of Mobile Banking on the Performance of Commercial Banks in Nigeria.

Ball, D., Coelho, P., \& Vilares, M. (2006). Service personalization and loyalty. https://doi.org/10.1108/08876040610691284

Ballou, B., Godwin, N., \& Shortridge, R. (2003). Firm Value and Employee Attitudes on Workplace Quality. https://doi.org/10.2308/acch.2003.17.4.329

Basci, E. (2014). Which Types Of Internet Banking Service Effects Bank's Income Statement? An Empirical Study For Turkey Between 2006 - 2013. The Macrotheme Review a multidisciplinary journal of global macro trends.

Baskarada, S. (2014). Qualitative Case Study Guidelines. The Qualitative Report, 19(40), 1-18. Retrieved from https://nsuworks.nova.edu/tqr/vol19/iss40/3/

Bello, D. (2010). The Effect of E-banking on Customer Satisfaction in Nigeria. Munich Personal RePEc Archive. Retrieved from https://mpra.ub.uni-muenchen.de/23200/

Berg, A. (2015) Improving customer satisfaction through personalization. University of Twelve. Retrieved from 
https://essay.utwente.n1/68785/1/Van\%20den\%20Berg_MA_EEMCS.pdf

Bondeson, F., \& Lindbom, I. (2018). Customer Loyalty in Mobile Banking - findings from the millennial generation. Uppsala University. Retrieved from http://uu.diva-portal.org/smash/record.jsf?pid=diva2\%3A1220425\&dswid=3527

Burtch, G., \& Hong, Y. (2014). What Happens When Word of Mouth Goes Mobile? Retrieved from Association for Information Systems.

Carvajal, S., Ruzzi, A., Nogales, F., \& Moreno, V. (2011). The effect of personalization and complaint handling on customer loyalty.

Chen, S. (2011). Understanding The Effects Of Technology Readiness, Satisfaction And Electronic Word-Of-Mouth On Loyalty In 3c Products. Australian Journal of Business and Management Research, 1. Retrieved from http://www.ajbmr.com/articlepdf/ajbmrv01n0301.pdf

Chiguvi, D. (2016). Effectiveness of Cell phone Banking on Service Quality in Commercial Banks in Botswana.

Cudjoe, A., \& Anim. P. (2015). Determinants of Mobile Banking Adoption in the Ghanaian Banking Industry: A Case of Access Bank Ghana Limited. https://doi.org/10.4236/jcc.2015.32001

Dineshwar, R., \& Steven, M. (2013). An Investigation on Mobile Banking Adoption and Usage: A Case Study of Mauritius. Proceedings of 3rd Asia-Pacific Business Research. Retrieved from https://pdfs.semanticscholar.org/214a/6fd937404db17c8c0a5e6a414d8a8f6fad86.pdf?_ga=2.220161305.146 $0547332.1564692052-1704551483.1564259992$

ElAziz, R., ElBadrawy, R., \& Hussien, M. (2014). ATM, Internet Banking and Mobile Banking Services in a Digital Environment: The Egyptian Banking Industry.

El-Qirem, I. (2013). Critical Factors Influencing E-Banking Service Adoption in Jordanian Commercial Banks: A Proposed Model. https://doi.org/10.5539/ibr.v6n3p229

English, L. P. (1996). Information Quality: Meeting the Customer Needs. Information Impact Newsletter, $2 i$.

Erkan, I., \& Evans, C. (2016). The influence of eWOM in social media on consumers' purchase intentions: An extended approach to information adoption. https://doi.org/10.1016/j.chb.2016.03.003

Eshlaghy, A., \& Bayanati, M. (2013). Ranking Information System Success Factors in Mobile Banking Systems with VIKOR.

Fawzy, S., \& Esawai, N. (2017). Internet banking adoption in Egypt: Extending technology acceptance model. https://doi.org/10.24052/JBRMR/V12IS01/IBAIEETAM

Friedman, B., Kahn, P., \& Howe, D. (2000). Trust online - communications of the ACM. https://doi.org/10.1145/355112.355120

George, A., \& Kumar, G. (2013). Antecedents of Customer Satisfaction In Internet Banking: Technology Acceptance Model (TAM) Redefined. https://doi.org/10.1177/0972150913501602

Grigorian, D. A., \& Manole, V. (2002). Determinants of Commercial Bank Performance in Transition: An Application of Data Envelopment Analysis. https://doi.org/10.1596/1813-9450-2850

Harelimana, J. (2017). Impact of Mobile Banking on Financial Performance of Unguka Microfinance Bank Ltd, Rwanda. https://doi.org/10.30876/JOHR.4.1.2018.26-40

Huili, Y., Shanzhi, L., \& Yinghui, Y. (2013). A Study of User Adoption Factors of Mobile Banking Services Based on the Trust and Distrust Perspective.

Ishida, K., Slevitch, L., \& Siamionava, K. (2016). The Effects of Traditional and Electronic Word-of-Mouth on Destination Image: A Case of Vacation Tourists Visiting Branson, Missouri. https://doi.org/10.3390/admsci6040012

Islam, A., \& Salma, U. (2016). Mobile Banking Operations and Banking Facilities to Rural People in Bangladesh.

Javabdeh, T., \& Ahmad, N. (2014). Developing Customer Positive Word-of-Mouth and Loyalty in Mobile Banking Services by Considering the Role of Trust and Security. Journal of Information Systems Research and Innovation. Retrieved from https://seminar.utmspace.edu.my/jisri/download/vol8/85.pdf

Jose, A., Kumar, G., \& Varghese, R. (2017). Factors Influencing Customer Adoption of Mobile Banking Services With Special Reference To Ernakulam District. 
Jun, M., \& Cai, S. (2001). The key determinants of internet banking service quality: a content analysis. https://doi.org/10.1108/02652320110409825

Kachembere, R., \& Choga, F. (2015). The Impact of E-marketing on Commercial Banks in Harare, Zimbabwe (1994-2014).

Karagül, A., \& Özdemir, A. (2012). Evaluation of Financial Information Quality Attributes: A Comparison from Turkey. International Journal of Business and Social Science, 3. Retrieved from http://www.ijbssnet.com/journals/Vol_3_No_23_December_2012/5.pdf

Kassim, N. (2017). Effect of Perceived Security and Perceived Privacy towards Trust and the Influence on Internet Banking Usage among Malaysians. International Academic Journal of Social Sciences, 4.

Kesharwani, A., \& Bisht, S. (2011). The impact of trust and perceived risk on internet banking adoption in India: An extension of technology acceptance model.

Kim, D., \& Benbasat, I. (2003). Trust- related arguments in internet stores: A framework for evaluation. Journal of Electronic Commerce Research. Retrieved from http://web.csulb.edu/journals/jecr/issues/20032/paper1.pdf

Kirk, J., \& Miller, M. (1986). Reliability and Validity in Qualitative Research SAGE. https://doi.org/10.4135/9781412985659

Kombe, S., \& Wafula, M. (2015). Effects of Internet Banking on the Financial Performance of Commercial Banks in Kenya a Case of Kenya Commercial Bank. International Journal of Scientific and Research Publications, 5. Retrieved from http://www.ijsrp.org/research-paper-0515/ijsrp-p4185.pdf

Kujur, T., \& Shah, M. (2015). Electronic Banking: Impact, Risk and Security Issues. International Journal of Engineering and Management Research, 55. Retrieved from http://www.ijemr.net/DOC/ElectronicBankingImpactRiskAndSecurityIssues(207-212).pdf

Lafraxo, Y., Hadri, F., Amhal, H., \& Rossafi, A. (2018). The Effect of Trust, Perceived Risk and Security on the Adoption of Mobile Banking in Morocco. https://doi.org/10.5220/0006675604970502

Litvin, S. W., Goldsmith, R. E., \& Pan, B. (2008). Electronic word-of-mouth in hospitality and tourism management. https://doi.org/10.1016/j.tourman.2007.05.011

Mahad, M., Mohtar, S., \& Othman, A. (2015). The Effect of Perceived Trust of Mobile Banking Services in Malaysia. International Academic Research Journal of Business and Technology. Retrieved from http://www.iarjournal.com/wp-content/uploads/IBTC2015-p1-7.pdf

Majali, T., \& Bohari, A. (2016). A Conceptual Model of Electronic Word of Mouth Communication through Social Network Sites: The Moderating Effect of Personality Traits. International Review of Management and Marketing. Retrieved from https://dergipark.org.tr/download/article-file/367361

Maroofi, F., Kahrarian, F., \& Dehghani, M. (2013). An Investigation of Initial Trust in Mobile Banking. International Journal of Academic Research in Business and Social Sciences. https://doi.org/10.6007/IJARBSS/v3-i9/228

Mashhour, A., \& Saleh, Z. (2015). Community Perception of the Security and Acceptance of Mobile Banking Services in Bahrain: An Empirical Study.

Masoud, E., \& AbuTaqa, H. (2017). Factors Affecting Customers' Adoptionof E-Banking Services in Jordan. https://doi.org/10.4018/IRMJ.2017040103

Mayer, R. C., Davis, J. H., \& Schoorman, F. D. (1995). An integrative model of organizational trust. https://doi.org/10.5465/amr.1995.9508080335

Mcknight, H., \& Chervany. N (2000). Trust and Distrust Definitions: One Bite at a Time. https://doi.org/10.1007/3-540-45547-7_3

Mehrad, D., \& Mohammadi, S. (2016). Word of Mouth effect on the adoption of mobile banking in Iran. https://doi.org/10.1016/j.tele.2016.08.009

Migdadi, Y. (2008). The Quality of Internet Banking Service Encounter in Jordan. Journal of Internet Banking and Commerce. Retrieved from http://citeseerx.ist.psu.edu/viewdoc/summary?doi=10.1.1.180.4094

Mohammad, A., \& Al-Tarawneh, K. (2014). The Intermediate Effect of the Adoption of Electronic Banking Services between the Word of Mouth and the Quality of Banking Services. 
Montazemi, A., \& Saremi, H. (2014). The Effectiveness of Electronic Word of Mouth on Consumers' Perceptions of Adopting Products/Services - A Literature Review.

Muhammad, A., Gatawa, N., \& Kebbi, H. (2014). Impact of Information and Communication Technology on Bank Performance: A Study Of Selected Commercial Banks In Nigeria (2001-2011).

Munoz-leiva, F., Luque-Martinez, T., \& Sanchez-Fernandez, J. (2010). How to improve trust towards electronic banking. https://doi.org/10.1108/14684521011099405

Mwange, J. (2011). The Impact of Mobile Banking on Financial Performance of Commercial Banks in Kenya. University of Niarobi. Retrieved from

https://chss.uonbi.ac.ke/sites/default/files/chss/JOHNSON\%20AMUGONGO\%20MWANGE\%20D61-6783 0-2011.pdf

Nair, V., Pinto, A., Chandran, L., \& Satheesh, S. (2017). Effect of Social Media on Management Students for Social Service and Sustainability. Recent Trends in Sustainability and Management.

Nicoletti, B. (2014). Mobile Banking: Evolution Or Revolution. Palgrave-MacMilland. https://doi.org/10.1057/9781137386564

Nso, M. (2018). Impact of Technology on E-Banking; Cameroon Perspectives. Int. J. Advanced Networking and Applications. Retrieved from http://oaji.net/articles/2017/2698-1528117916.pdf

Okereke, E., \& Nzotta, S. M. (2009). Financial Deepening and Economic Development of Nigeria: An Empirical Investigation. African Journal of Accounting, Economics, Finance and Banking Research, 5(5). Retrieved from https://papers.ssrn.com/sol3/papers.cfm?abstract_id=1534212

Perdigoto, M., \& Picoto, W. (2012). Analysing Intention And Action In Mobile Banking Services. Portuguese Journal of Management Studies, Xvii. Retrieved from

https://ejms.iseg.ulisboa.pt/files/9.PJMS.Vol17.Issue2_Analysing_intention_and_action_in\%20_mobile_ba nking_services.pdf

Phua, J., Jin, S., \& Kim, J. (2016). Gratifications of Using Facebook, Twitter, Instagram, or Snapchat to Follow Brands: The Moderating Effect of Social Comparison, Trust, Tie Strength, and Network Homophily on Brand Identification, Brand Engagement, Brand Commitment, and Membership Intention". https://doi.org/10.1016/j.tele.2016.06.004

Pitts, C. (1995). Motivating Your Organization: Achieving Business Success through Reward and Recognition. McGraw-Hill Education Europe Imprint McGraw-Hill Publishing Co.

Ringle, C., Henseler, J., \& Sarstedt, M. (2015). A new criterion for assessing discriminate validity in variance-based structural equation modeling. Journal of the Academy of Marketing Science. Retrieved from https://link.springer.com/article/10.1007\%2Fs11747-014-0403-8

Rousseau, D. M., Sitkin, S. B., Burt, R. S., \& Camerer, C. (1998). Not So Different after All: A Cross-Discipline View of Trust. Academy. https://doi.org/10.5465/amr.1998.926617

Salamah, N. (2017). Effect of Electronic Banking Services on Bank Transactions. International Journal of Economics and Finance, 9. https://doi.org/10.5539/ijef.v9n2p111

Saleem, A., \& Ellahi, A. (2017). Influence of Electronic Word of Mouth on Purchase Intention of Fashion Products on Social Networking Websites. Pakistan Journal of Commerce and Social Sciences, 11.

Sarfaraz, J. (2017). Unified Theory Of Acceptance And Use Of Technology (Utaut) Model-Mobile Banking. Journal of Internet Banking and Commerce, 22(3). Retrieved from http://www.icommercecentral.com/open-access/unified-theory-of-acceptance-and-use-of-technology-utautmodelmobile-banking.php?aid $=86597$

Senthilkumar, S., Ramachandran, T., \& Anand, S. (2013). The Influence of Electronic Word-Of-Mouth over Facebook on Consumer Purchase Decisions. International Journal of Management, 4. Retrieved from: https://www.researchgate.net/publication/256492963_THE_INFLUENCE_OF_ELECTRONIC_WORD-OF -MOUTH_OVER_FACEBOOK_ON_CONSUMER_PURCHASE_DECISIONS

Shaikh, A., \& Karjaluoto, H. (2016). Mobile banking services continuous usage - Case study of Finland. https://doi.org/10.1109/HICSS.2016.189

Taha, A. (2013). Profitability of the Jordan Banking Sector: Panel Evidence on Bank Specific and Macroeconomics Determinants. Eastern Mediterranean University. Retrieved from 
http://i-rep.emu.edu.tr:8080/jspui/bitstream/11129/613/1/Taha.pdf

Tantrabundit, P., Phothong, L., \& Chanprasitchai, O. (2018). The Effects of Negative Electronic Word-of-Mouth and Webcare on Thai Online Consumer Behavior.

Tavallaei, R., Shokouhyar, S., \& Pour, F. (2015). Effects of Electronic Banking Services Adoption on Banks' Performance via Balanced Scorecard Approach Using Fuzzy TOPSIS. International Journal of Social Sciences and Humanities Research, 3. Retrieved from http://ijsshrjournal.com/img/download/katalog/Paper_15.13.5.pdf

Thiel, M. (2015). Finance and economic growth - a review of theory and the available evidence. Directorate General Economic and Financial Affairs (DGECFIN), European Commission. Retrieved from https://econpapers.repec.org/paper/eufecopap/0158.htm

Tong, C., \& Australia, A. (2012). The Influences of Service Personalization, Customer Satisfaction and Switching Costs on E-Loyalty. https://doi.org/10.5539/ijef.v4n3p105

Waarden, L. (2015). Effects of loyalty program rewards on store loyalty. https://doi.org/10.1016/j.jretconser.2015.01.001

Wang, B., \& Shan, C. (2013). The Effect of Online-to-Mobile Trust Transfer on the Foundation of Mobile Banking Trust. https://doi.org/10.4236/cn.2013.51B025

Wattegama, E., \& Qing, P. (2014). Impact of Electronic Word of Mouth on Brand Evaluation in Times of Negative Publicity: A Conceptual Framework. European Journal of Business and Management, 6. Retrieved from https://www.iiste.org/Journals/index.php/EJBM/article/view/17367

Wessel, M., \& Thies, F. (2015). The Effects of Personalization on Purchase Intentions for Online News: An Experimental Study of Different Personalization Increments. https://doi.org/10.18151/7217524

Yan, X., Shah, A., Zhai, L., Khan, S., \& Shah, S. (2018). Effect of Mobile Electronic Word of Mouth (EWOM) on Consumers Purchase Intentions in the Fast-Causal Restaurant Industry in Indonesia. https://doi.org/10.24251/HICSS.2018.479

Zhao, Y., Liu, Y., Lai, I., Zhang, H., \& Zhang, Y. (2016). The Effects of Attitudes and Engagement on Electronic Word of Mouth (eWOM) of Mobile Sensor Computing Application. https://dx.doi.org/10.3390\%2Fs16030391

Zikmund, W. G., Babin, B. J., \& Carr, J. C. (2013). Business research methods. South-Western College Pub; 9 edition Mason, Ohio.

\section{Copyrights}

Copyright for this article is retained by the author(s), with first publication rights granted to the journal.

This is an open-access article distributed under the terms and conditions of the Creative Commons Attribution license (http://creativecommons.org/licenses/by/4.0/). 